\title{
Māori Cultural and Bodily Rebirth in Alan Duff's Once Were Warriors Trilogy
}

Laura Singeot

\section{OpenEdition}

1 Journals

Electronic version

URL: https://journals.openedition.org/ces/10327

DOI: $10.4000 /$ ces. 10327

ISSN: 2534-6695

Publisher

SEPC (Société d'études des pays du Commonwealth)

\section{Electronic reference}

Laura Singeot, "Māori Cultural and Bodily Rebirth in Alan Duff's Once Were Warriors Trilogy",

Commonwealth Essays and Studies [Online], 44.1 | 2021, Online since 15 January 2022, connection on 03 February 2022. URL: http://journals.openedition.org/ces/10327 ; DOI: https://doi.org/10.4000/ces. 10327

This text was automatically generated on 3 February 2022.

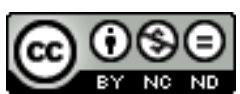

Commonwealth Essays and Studies is licensed under a Licence Creative Commons Attribution - Pas d'Utilisation Commerciale - Pas de Modification 4.0 International. 


\title{
Māori Cultural and Bodily Rebirth in Alan Duff's Once Were Warriors Trilogy
}

\author{
Laura Singeot
}

1 In Aotearoa/New Zealand literature, the Renaissance movement that started in the 1970s was marked by the return to Māori cultural elements in novels written by emerging Māori writers. Thus, Witi Ihimaera was the first Māori writer to extensively use Māori mythology in his novel The Whale Rider (1987). Such a shift was not only thematic but also became intertwined with questions of genre, specifically that of the novel, which was considered as the European genre par excellence. Ian Watt in The Rise of the Novel (1957) points out the individualistic turn of the Renaissance in Europe: he observes that "from the Renaissance onwards, there was a growing tendency for individual experience to replace collective tradition as the ultimate arbiter of reality" $(1957,15)$. The genre of the novel developed as a response to the social and historical changes European society experienced at that time, as explained further by Watt:

The concept of individualism [...] posits a whole society mainly governed by the idea of every individual's intrinsic independence both from other individuals and from that multifarious allegiance to past modes of thought and action denoted by the word 'tradition' - a force that is always social, not individual. The existence of such a society, in turn, obviously depends on [...] an ideology primarily based, not on the tradition of the past, but on the autonomy of the individual, irrespective of his particular social status or personal capacity. $(1957,60)$

The transposition of the genre of the novel to the Pacific literary context entails that characters have different experiences of subjectivity. This is the case in Alan Duff's trilogy: Once Were Warriors (1990), What Becomes of the Broken Hearted (1996), and Jake's Long Shadow (2002). First, quite paradoxically it seems, characters are more often than not feeling estranged from their own community, as if exiled from their own kin. This estrangement correlates with a fragmented Self, or rather with "other selves." Eventually though, characters, especially the protagonist Jake, seem to come to terms with their fragmented subjectivity: the rebirth of the characters rests on a form of 
narrative empowerment expressed through the distinctive use of parentheses that enhances voice and uncovers multiple layers of self-consciousness. Finally, the progressive shift from a unified collective that drowns the individual to a supportive community provides the cultural foundation for the rise of the individual, insofar as protagonists achieve some kind of completion and fulfilment only when they successfully reconnect with their community.

\section{Being exiled in one's community}

3 In Duff's novels, characters first seem to experience erasure within a harmful, "deprived" and "lost" community from which they feel estranged. From Once Were Warriors's incipit onwards, Beth insists on her alienation from her own community, which appears to be the result of the social context, as she describes what she calls "misery boxes":

For hours at a time, sometimes, she'd watch the mirrors of her existence outside [...] and feel like a spy. Spying on my own people. Them out there. Us. The goingnowhere nobodies who populate this state-owned, half of us state-fed, slum. The Māoris. Or most ofem are. (Duff 2004, 7)

The hesitation between the pronouns "us/them" illustrates two contrasted features of one's reflection in a mirror ("the mirrors of her existence"): similarity and difference. Beth feels estranged from her community, as if in exile within it: "[...] why she wanted to be different from everyone else, wasn't she satisfied and who'd she think she was anyway?" (9). However, this estrangement does not amount to a possible emancipation from it or the potential recognition of Beth as a subject; her description does not match the "individualisation" that defines a novelistic character (Watt 1957, 18). Therefore the question "who'd she think she was anyway?" becomes purely rhetorical and does not bring any answer - any other than "no one," that is. It negates Beth's subjectivity, preventing her from successfully emancipating herself from her community. Oscillating between identification and differentiation, this character, though narrating the scene, cannot escape from "the mirrors of her existence." The singularity of her own existence, that could have successfully led to her own inscription as a single subject, cannot prevail over its ad infinito duplication into "nobodies" in front of her eyes. The individual facing such an overwhelming reduplication cannot compete, and the plural comes to encapsulate the singular, as the collective does with the individual. This plural even paradoxically and indirectly characterises Beth and seems to add to her confusion since her house is implicitly defined in its resemblance to the others: those "misery boxes" are all the same. This alienation is also transposed onto a linguistic level when the characters talk about themselves, in a way that recalls the "splitting in two" mentioned by Sartre in his "Black Orpheus," the character "already exiled from himself" $(1951,224)$, since they quite often use the third-person singular as a self-referring device. When Beth confronts her son Nig, after he has joined the gang of the Black Fists, she refers to herself as "a woman": "son, you got to think of the future. Nig saying, what future? No future for a Māori. And walking off. Rocked a woman to the core" $(2004,16)$. This narrative strategy is not a Māori preserve, since Trambert, a Pākehā, also uses this trope during an instance of internal focalization: "a man'd never seen one [marae] so close nor realized how magnificently complex was the art of a people he knew, not socially, a single member of" (133). Even though the expressions "a man" or "a woman" appear in passages written in the third-person 
singular, leading sometimes the narration to oscillate between stream of consciousness and internal focalisation, their use reveals somehow a different layer or another degree of this third person: it appears to be a little less focused on the individual and quite undetermined, which arguably tends to expand this experience to members of the same community and universalise it in a way. Beth's rant is easily transferrable to other Māori mothers, and hopefully so is Trambert's recognition of Māori culture to other Pākehā. The use of the third person by the characters themselves creates a distancing effect, as if they had become alienated from themselves, especially since this occurs through internal focalisation, which usually makes a character's inner thoughts more accessible to the readers. This recalls the trope of the mirror image, relying at the same time on identification and differentiation, on distance and closeness.

5 Another protagonist, Polly, is mostly depicted through reflections and repetitions of scenes that appear as rewritings through the narration: she is indirectly defined through other women, her mother and elder sister, Grace. In What Becomes of the Broken Hearted, she explicitly re-enacts the very first scene of the trilogy when Beth assesses her bruises in a mirror before accusing her community of being the perpetrators of their own doom. Polly does the same, functioning as her mother's reflection:

Before the mirror as she remembered her mother before the cracked bathroom mirror back in Rimu Street, Pine Block, looking at her beating wounds about once every month, maybe more or it could have been less, Polly wasn't counting the times, just the hours, the days, the years, for when she'd be old enough to leave all this behind her. $(1998,84)$

Here, Polly appears as a cracked mirror, broken from the inside, once more oscillating between identification (with her mother) and difference, when she counts the days until she will eventually be able to escape from the community, her own, that brings her down when she tries to succeed. Her peers are the ones who belittle and beat her up, i.e. other girls from school:

All for working hard at school. Not for being Maori suffering at the hands of whites (as some did, no denying) but for being Maori suffering at the hands of Maori to whom the whole notion of success, having goals, being ambitious, was as if a threat to them, the collective. (They beat me up because I want a better life?) (84)

6 The Māori community seems as harmful as the Pākehā's here, if not more. Even if its members wanted to attain success, through social mobility or success at school for example, they would not be able to: improving their lives would lead them to emancipate themselves from the community and loosen collective ties, and such individual rebirth and rising above other members of their community, relying on individual empowerment, is not tolerated by the Māori schoolgirls. Two opposed dynamics are at work: the individual's psychological isolation in their community prevails, but simultaneously the individual cannot free themselves from the Māori community for fear of being considered as a traitor. This idea is not without recalling Spivak's notion of the "double-bind," the opposition and yet mutual definition and coconstruction of two subject positions (1993, 131-33). Here, instead of deriving from Western society, this double-bind between the collective and the individual is experienced within the Māori community. This seems to be all the more hurtful to Polly, because violence may not come from Pākehā but from her own community. Polly continues:

No, it had to happen from members of her own race, the same who claimed they were so staunch to each other. The fucken liars who claimed they knew and 
understood more as a people about love than the whites they, yes, hated. (Fuck

them! I hate them!) Why don't they leave me alone? (Duff 1998, 85)

The young girl does not only feel estranged from her community but the group also seems to want to destroy her for being too ambitious, for wanting to break away from its harmful influence. All ambition is nipped in the bud, mirrors only appear as broken, offering a jarring reflection of the individuals that struggle to distinguish themselves.

Consequently, it seems that subjectivity is never stable, as the tropes of the mirror and the reflection suggest: similarity and likeness give way to discordance and difference, leading to an ontological questioning of the individual. Gilles Deleuze underlines the necessity to turn to the difference that is inherently part of all repetition, studied here through the trope of the reflection:

Being neither the identity of the Same nor the equivalence of the similar, repetition is found in the intensity of the Different. [...] In short, the double, the reflection, the simulacrum opens up at last to surrender its secret: repetition does not presuppose the Same or the Similar - these are not its prerequisites. It is repetition on the contrary which produces the only "same" of that which differs, and the only resemblance of the different. $(1990,288-89)$

Hence the instability of subjectivity: in Duff's novels, the repetition that necessarily accompanies the mirror image only serves to enhance difference, until it estranges characters from themselves. If identification can only be achieved through one's differentiation from others, it also paradoxically questions the cohesion and homogeneity of the subject, contrasting once more with traditional characterisation as it developed in European literature from the Renaissance onwards.

\section{Traces of other selves}

One of the structural moments in Once Were Warriors happens when Grace observes Charlotte Trambert outside her house at night (because the former will eventually commit suicide in front of Charlotte's window). They are alike but there is a whole world in between: Grace spies on Charlotte who cannot see her because of the night, it is as though the window separating them was in fact a one-way mirror, underlining the fact that there is a clear division between those two worlds, creating a form of "social invisibility" (Král 2014, 54). The boundary represented by the window is not only a physical one, but a cultural and social one as well. But Grace also feels estranged from her own community, mostly because of her rape (she thinks her rapist is her father) and this will lead her to become estranged from her own self. According to Françoise Král, this type of invisibility rests on the rejection of the individual's potential:

If invisibility is undeniably a phenomenon which occurs in a given location, the origin of a person's invisibility is his/her failure to translate his potential visibility into one which is acknowledged by others. This potential can be activated in different ways [...]. But the problem is more for those who already are invisible and whose lapse into invisibility has become a long-term condition from which they cannot escape. $(2014,66)$

In her moments of discordant self-reflexion, Grace sees what she could have been, and this is that haunting presence of her "potential" that is constantly repeated throughout the novels, even after she has committed suicide. During Grace's tangi (funeral), her mother Beth thinks about "A girl, a life, a supposed potential, gone forever" (Duff 2004, 
123), while the omniscient figure, Telescope Man, concludes the chapter dealing with Grace's suicide as follows:

But eventually there was no more light along that back view of state houses. Only the stars, as always, up there shining on. Though a man in town owned a telescope and had much learning, he could have told you that even they, the stars, go out. So what's a life? (Potential, sir. It's an unrealised potential). (119)

This allows the reader to catch a glimpse of what could have been, which turns Grace's absence into a haunting presence in the other books of the trilogy. The notion of potential hollows out the character's subjectivity and annihilates it, especially here, in that final self-destruction that is suicide.

Different levels in the narration and typography emphasize the distinction to be made between different levels of the self, the best example of this being the very distinctive use of parentheses. In "Ethnicity and the Post-Modern Arts of Memory," Michael Fischer evokes "the use of alternative selves [that challenges] dominant hegemonic ideologies" (1986, 213), calling this process "multidimensionality" (201), which perfectly describes what happens in Duff's novels. This is distinct from recovering one's voice, as the narration already integrates various streams of consciousness. With the alternative selves, readers are faced with another layer that embodies the struggling self, the dissident self, rejecting and questioning Western representations, as part of the process Eva Rask-Knudsen called the "epistemic violence" experienced by Indigenous peoples $(2004,90)$. The text becomes not only a palimpsest with different narrative layers, but also an ontological palimpsest, giving access to different levels of voice, awareness and self. Thanks to parentheses, the narration displays "the subversiveness of alternative perspectives for the taken for-granted assumptions of dominant ideologies" (Fischer 1986, 223). However, it can also be perceived as ambivalent because it insists on the fragmentation of selves and participates in the loss of unity of the self, in a necessary step on the way to emancipation from epistemic violence.

Parentheses signal silent thoughts of the characters, showing another version of reality, the way they interpret it or to what extent this reality differs from Western perceptions. Their use also gives visible form to subjective imprisonment: if those voices cannot be heard and remain nonverbalised thoughts, it is because they are censored as much on the page as in society. However, they still make those thoughts available to readers while also operating as an objective-correlative for the marginalisation of Māori in Aotearoa / New Zealand where they reveal a geographic and social divide, as Māori and Pākehā live in different neighborhoods. First, parentheses aim at showing what would otherwise be left unseen, hidden or silenced, as can be seen in: "[he wanted] his own girlfriend who he could (secretly) love" (Duff 1998, 17). Similarly, this is how Beth shares with the readers a stark criticism of her own community, typically something that she could not have voiced for fear of triggering Jake's anger and receiving subsequent blows. Anyway, who would listen to her? Beth denounces alcohol as devastating her community:

Horse and carriage, love and marriage, smoke and beer. (Beer and fists. Beer and personality change. Beer and...) [...] (Beer and happiness -?? Happiness? For me it is. Beer and culture. Culture? Beer and Māori culture. It's our lifeblood. We live for our beer. My parents did, and as for Jake's, the stories he's told me about how they drank. Any wonder he's half mad.) (Duff 2004, 41) 
To her, alcohol first results in physical violence: "(Beer and fists. Beer and personality change. Beer and...)." However, after mentioning her own definition of happiness ("For me it is..."), she goes back to a more essentializing vision of alcohol which comes to define, and nearly keep alive Māori community and culture ("We live for our beer"). It is no wonder that such thoughts remain unsaid and should be kept hidden between parentheses. Beth keeps other thoughts secret since they recall another kind of essentialism at the core of nineteenth-century racist ideology. She mentions her "race" as possibly being the reason for her daughter's suicide. To her, the main cause may be hereditary, and she blames her Māori roots, even though it may also be understood as a way of attenuating her own guilt as a mother who has not succeeded in protecting her child:

Only guilt left. And a slow-building anger - no, a rage. A rage building up in her. [...] And the nagging thought: (Oh please don't let it be...?) that her race, Grace's facthood of being Māori (deprived, I don't know...) might have been the cause? $(2004,122)$

13 As Beth tries to understand what may have caused Grace's suicide, the juxtaposition of parentheses allows the readers to follow her track of thought, from denial to justification: this event is so hard for her to process that the first parentheses contain an ellipsis under the form of a supplication, “(Oh please don't let it be...?)." Then, she tries to explain or justify it with the idea of deprivation, but fails to be utterly convinced: "I don't know." In the narration, parentheses reveal what is lurking under the surface: the character's self-awareness and questioning appear in the body of the text, since both "systems of representation," that of Pākehā society and that of the Māori, appear side by side. Thus, the narration illustrates the passage from "the epistemology of blindness to the epistemology of seeing," to borrow the words of Boaventura de Sousa Santos $(2014,154)$. Eventually, such self-awareness, in its frailty, may even be threatened by characters themselves who come to be terrified by what could be disclosed. For example, Rita makes Jake believe that it is possible for her to come back to his place for a date:

She lifted a finger atim, Jake Heke, you'd better have some [sheets] when I get there or... (Or what? She won't come see me? Is that what I want?) Asking himself was he really trying to discourage her and if so, why? (Cos I'm afraid, the voice jumped out at him before he could ready himself against hearing it. And it kept going. Cos I'm frightened of getting close to someone. I'm frightened of -) Fuckit. He got back on top of the inner voice, or enough to move this on without turning it back to the hopeless point it was at. (Duff 1998, 131, emphasis added)

These parentheses give readers direct access to that "inner voice" that Jake does not want to hear anymore, for fear it may finally be telling the truth. Consequently, this textual palimpsest reflects that other palimpsest composed of different layers of consciousness. The Indigenous voice is reintegrated in the text, and it may even be considered as the emergence of a political conscience. In Once Were Warriors, Nig, Grace's brother, concludes with quite a disembodied voice, nearly anonymised by its poetic generalisation: "(Yet inside all this unspokenness like some uncoiled spring of beauty, unnerstandin, just achin to unleash itself)" (Duff 2004, 141). Nig may be offering the best illustration of the purpose of those parentheses in the trilogy, defining the Indigenous voice, imprisoned, restrained, and yet present, visible, and adopting for its own benefit the Western rules of punctuation. The use of the parenthesis is political, not only because it enables the readers to access another layer of subjectivity, but also because it contrasts with conventional typographic rules: information placed between 
parentheses is usually nonessential, something that could have been left out with no real loss of meaning. Here, parentheses have become a prevailing part of the text and operate as (a) "supplement," recalling Gayatri Spivak's definition of the verb "to supplement," which does not evoke something you can discard. On the contrary, it means to "fill a hole in as well as add to" (Spivak 2003, 42). Rebirth here is about filling in what was erased, but also about adding new things, giving a new direction to the representation of the individual.

\section{From "disembodied minds" (Lattas 1986, 260) to "embodied sovereignty" (Hokowhitu 2014, 278)}

In Duff's novels, it seems at first that the readers are faced with the exact opposite of Bhabha's understanding of the novel as having "a nation forming role" or as "a contemporary, practical means of creating a people" (Brennan 1990, 50): the community seems to fall apart, as the individual disintegrates, and is presented as fragmented, deprived and lost. The subject as it is primarily the object of the Western gaze loses all prospect of emancipation as well as the possibility for a better life. The narration mistreats the subject on an epistemological as well as ontological level: deprived of any kind of perspective, lost in alcohol and cigarette fumes and constant fights, the Māori sink even deeper "in perpetual darkness" (Duff 2004, 83), systematising the destruction of the subject and of their community, which fails at first in its unifying, inclusive and emancipatory role. Yet, this may be seen as the first step to a radical change, from "disembodied minds" to "embodied sovereignty." The expression "disembodied minds" is borrowed from Andrew Lattas's article "Essentialism, Resistance, Memory" which focuses on the Australian context. However, Lattas's remarks appear to be quite relevant and transferrable to Aoetaroa / New Zealand:

Under the label of rejecting biologism, Aborigines are to produce themselves as disembodied minds. Some white intellectuals like Thiele, Keeffe and Hollinsworth even want Aborigines to abandon the positing of cultural essences for they see images of a primordial past or being as capturing a stability and permanent difference which they find politically dangerous and irrelevant. This policing of images of Aboriginal authenticity by Whites participates in the very processes of cultural hegemony and cultural genocide [...]. (1986, 260-61)

While emphasizing the dangers lying in the essentialisation of distinctive physical and cultural features, this quote also insists on the pitfalls of such an idea; the fact that it may reproduce what it strongly tries to debunk. Conversely, Brendan Hokowhitu's expression "embodied sovereignty" refers to what should be aimed at, "including the existential and everyday properties of Indigenous culture - that is, what culture 'feels like' as opposed to the antiquation of Indigenous culture, which enables the temporal dislocation of Indigenous Peoples away from the present" $(2014,278)$. Lattas's and Hokowhitu's quotes literally illustrate that necessary shift in paradigm from the fragmentation of the self to the reinstatement of the Māori body as a privileged site of the construction of identity, as is underlined by the contrast between "disembodied" and "embodied" in the phrases they use. Nevertheless, that shift is two-fold because of the passage from a plural, "minds," to a singular, "sovereignty": "minds" in the plural may refer to the rejection of the Indigenous body as it was linked to nineteenthcentury essentialist considerations, whereas "sovereignty" in the singular can be 
achieved through a renewed sense of community, of belonging which strongly relies on self-representation as well. ${ }^{2}$ Yet, far from going back to the essentialisation advocated by eighteenth- and nineteenth-century racist ideology for example, this transition enables Indigenous communities to define sovereignty on their own terms and transform it into a partially self-emancipatory practice. They reassert themselves as agents thanks to the sovereignty that they regain over their bodies and through them, both as proof of their belonging to the community and as the means thanks to which they reassert their cultural identity. Once more, in his article, Andrew Lattas criticises Western academics for considering Aboriginal identity as purely "relational," rather than embodied:

[Aboriginal culture] is to be stripped of its essentialising mythology and folklore and introduced to modern theoretical ideas which emphasise the contextual and relative nature of any identity. [...] The demand that Aborigines produce their popular consciousness along the lines of a social theory of identity is a request that they become conscious of themselves as purely relational identities; they are to be resisters without producing an essence for themselves. [...] In effect, a white moral gaze refuses Aborigines an identity politics that is grounded in them taking up their bodies as an imaginary space. (247-48)

This idea, strongly opposed by Lattas, finds its literary expression in Duff's novels: the characters reclaim their bodies, thanks to cultural and collective practices. This is not a mere subversion or opposition to the ideological dominant system, but rather becomes a means for them to reappropriate their corporeality as a self-defining feature and to turn this new essentialising vision into a political and self-emancipatory practice.

Consequently, subjectification, or the reinscription of the character in the novel as a subject, is first suggested by this return to the body, which then results in the recovery of one's identity. This idea is introduced by the reference to former meanings of bodily practices, for example the original meaning of Māori facial tattoo, Te Moko, as an "exquisite design from days when a man's face was his meaning, spoke his meaning, were his written form of communicating who he was when no other form of writing existed" (Duff 2002, 186). As Te Moko tells the story of the warrior, his identity is displayed for everyone to see, conveying this message as a written language would, except that it is deeply chiseled in his face. This is the first hint of that "embodied sovereignty," to borrow Hokowhitu's words. According to him, during colonial times, the construction of Indigenous identity followed what he terms a "body logic," which means that identity was essentially linked to the body and the bodily practices of those communities:

What it means or meant to be an authentic and tradition-abiding Indigenous subject was materialized and reified by bodily practices, including haka. [...] [T]he Indigenous subjects became self-conscious and constituted themselves as social subjects within the colonized Self/Other dialectic, through and because of their body and body practices. $(2014,284)$

To undertake that process of self-definition and cultural emancipation, to tear oneself away from subjugation (when being a "subject" in a colonial regime, or "being subjected to" a treatment) and really engage in an emancipatory subjectivisation (recovering subjectivity), Hokowhitu advocates "embodied sovereignty" which, he says,

refers to a critical bodily practice that brings into question those subjugating forces written upon the Indigenous body, that is, the very materiality of Indigenous existence, while affirming the complexity, diversity, and multidimensional ways of being Indigenous. Moreover, practices of embodied sovereignty must be aware of the way that discourses of Indigenous authenticity and tradition haunt them. As a 
consequence, part of the study of embodied sovereignty should be an analysis of how the spectre of tradition remains written upon the Indigenous body [...]. (2014, 295-96) continuity in warriorhood also appears when Jake joins the hunting parties thrown by the Douglas brothers: "Sunlight bathed [this canyon] and participants in this ancient practice (ceremony, initiation, rite) man had made of hunting" (Duff 1998, 98). Both hunting and playing rugby hark back to ancestral practices and re-actualise them in the present situation: they enable the character to experience and weave those threads eventually connecting him to his culture, community and past. Body and "bodily practices" become the privileged locus of cultural reappropriation: for example, Grace's tangi (funeral) ends on a haka which is described as the last stage of a "cultural journey." It is also what inscribes the community as such at the end of the first novel: "all hell broke loose as the thirty and more men and women launched into a haka" (Duff 2004, 127). Community is reassessed through its sheer physicality, even before the plurality of individuals merges into a unified whole: from the plural to the singular, "thirty and more legs rising as one" (127). Even though one could argue that it is just another instance of fragmentation, bodies perform together and it is that cultural practice and performance that creates community here, that recalls its birth or rebirth "rising as one." The body is not savage and primitive anymore, as eighteenth- and nineteenth-century Western thought would have it; rather it is redefined on the terms of the Māori community, unified in a self-awareness that becomes an awakening, reaching back to the past and tradition:

Words exploded forth: KAMATE! KAMATE! Each line, every encrazed utterance a spitlaced outpouring of WAR! WAR! WAR! And inwritten with (atavistic) beat, this terrible animal rhythm of yet the highest order. Man, it was a beautiful, crazy war-dance; like a mad-fuckin ballet, man; like they were risen from a swamp. (A primeval swamp.) (127)

21 Animality, another marker of those primary Western discourses, is qualified by the reference to transcendence ("highest order") but also by the link with tradition. The past is reinscribed here in the present thanks to performance, which also links those bodies together into one same community.

\section{Rebirth as an "Old/New combo"}

The failure of the individual's characterisation and the construction of their subjectivity following Western literary tradition pave the way for another form of subjectivity grounded in the collective: far from merging the individual into a multitude, it acts as a revealer. As the Māori community did not experience the same 
shift toward the individual that marked a change in European thought and literature in the nineteenth century, one individual's relation to their community remained essential in the construction of their very self. The idea of community relies intrinsically on a "shared purpose" which binds individuals and makes them reach some kind of collective awareness and reflexivity which is not only political but also epistemological. Only then can they overcome the first misrepresentations imposed on them. In Duff's novels, the Māori body is the place where past and present coalesce thanks to specific cultural practices, whether they are individual (such as Te Moko) or collective (rugby or hunting). There is a paradigm shift from the individual to the community, whose members can achieve a higher degree of subjectivity and definition which is then transferred back onto the individual. The Māori characters' subjectivity is constructed on their own terms and does not depend on the literary changes that characterise the novelistic genre, mostly due to contextual evolutions - whether they are social or historical - that happened in Europe.

Accordingly, in the last opus of the trilogy, Jake's Long Shadow, Jake's emancipation is made possible by his renewed relation to his community, mostly through sports. It is signaled in the clear progression of his questioning that appears in the titles of the chapters. This ontological and epistemic questioning, which displays a specific use of parentheses in chapter 11 - "Who made Jake (me?) What made me?" - leads to the assertion of his progressive shift in perception and his realisation by chapter 47 that a change is necessary: "Same picture, different eyes." It finally leads to the concluding chapter (48) entitled "The old/New combo" - which represents the very definition of what rebirth represents in Duff's novels.

\section{BIBLIOGRAPHY}

BRENNAN, Timothy. 1990. “The National Longing for Form.” In Nation and Narration, edited by Homi K. Bhabha, 44-70. London: Routledge.

DELEUZE, Gilles. 1990. The Logic of Sense. Translated by M. Lester and C. Stivale. 1969. London: The Athlone Press. Originally published as Logique du sens (Paris: Éditions de Minuit, 1969).

DOY, Gen. 2000. Black Visual Culture: Modernity and Postmodernity. London: I.B. Tauris Publisher.

DufF, Alan. 1998. What Becomes of the Broken-Hearted? 1996. Milsons Point, NSW: Vintage.

DuFF, Alan. 2002. Jake's Long Shadow. Auckland: Vintage Books.

DufF, Alan. 2004. Once Were Warriors. 1990. Auckland: Vintage.

FISCHER, Michael M.J. 1986. "Ethnicity and the Post-Modern Arts of Memory." In Writing Culture: The Poetics and Politics of Ethnography, edited by James Clifford and George E. Marcus, 194-233. Berkeley: University of California Press.

HALL, Stuart. 1997. Representation: Cultural Representations and Signifying Practices. Culture, Media and Identities Series. Bath: Sage Publications \& Open University. 
НокошнітU, Brendan. 2014. "Haka: Colonized Physicality, Body-Logic, and Embodied Sovereignty." In Performing Indigeneity: Global Histories and Contemporary Experiences, edited by Laura R. Graham and H. Glenn Penny, 273-304. Lincoln: University of Nebraska Press.

KRÁL, Françoise. 2014. Social Invisibility and Diasporas in Anglophone Literature and Culture: The Fractal Gaze. New York: Palgrave Macmillan.

LATTAS, Andrew. 1993. "Essentialism, Memory and Resistance: Aboriginality and the Politics of Authenticity." "The Politics of Representation and the Representation of Politics." Special issue, Oceania 63, no 3: 240-67.

RASK-KNUDSEN, EVa. 2004. The Circle and the Spiral: A Study of Australian Aboriginal and New Zealand Maori Literature. Cross/cultures. Amsterdam: Rodopi.

SANTOS, Boaventura de Sousa. 2014. Epistemologies of the South: Justice against Epistemicide. Boulder: Paradigm Publisher.

SARTRE, Jean-Paul. 1951. "Black Orpheus." Translated by S.W. Allen. Présence africaine, no. 10/11: 219-47.

SPIVAK, Gayatri Chakravorty. 1993. Outside in the Teaching Machine. New York: Routledge.

SPIVAK, Gayatri Chakravorty. 2003. Death of a Discipline. The Wellek Library lectures in critical theory. New York: Columbia University Press.

WATT, Ian. 1957. The Rise of the Novel: Studies in Defoe, Richardson, and Fielding. Berkeley: University of California Press.

\section{NOTES}

1. This expression is borrowed from Stuart Hall, who defines those systems as follows: "Members of the same culture must share sets of concepts, images and ideas which enable them to think and feel about the world, and thus to interpret the world, in roughly similar ways. They must share, broadly speaking, the same 'cultural codes'. In this sense, thinking and feeling are themselves 'systems of representation', in which our concepts, images and emotions 'stand for' or represent, in our mental life, things which are or may be 'out there' in the world." $(1997,4)$

2. This transfer also recalls the distinction made by Gen Doy in Black Visual Culture, between "objectified bodies" and “embodied subjects" (Doy 2000, 111).

\section{ABSTRACTS}

This article examines what happens in Alan Duff's trilogy, Once Were Warriors (1990-2002), to the Western novelistic device of individualisation of characters that takes its roots in the European Renaissance. In Duff's novels, the development of characters is reconfigured through their relation to others as they experience a form of cultural and bodily rebirth in their own community. The trilogy thus offers an alternative to traditional Western characterisation, by deploying other ways of constructing subjectivity. 
INDEX

Keywords: subjectivity, sovereignty, Māori, individualisation, community

\section{AUTHOR}

\section{LAURA SINGEOT}

CREA, Université Paris Nanterre

Laura Singeot is a researcher at CREA, Paris Nanterre Université and teaches English at university Paris Saclay. She is interested in the representations of Indigeneity in contemporary Indigenous literatures from Australia and Aotearoa-New Zealand. She has also studied and published on Australian science-fiction, speculative and dystopic young adult fiction. She is also researching new museology and Indigenous visual art, focusing on its integration into global networks of creation, curation and reception. 